Vietnam Journal of Mechanics, VAST, Vol. 29, No. 3 (2007), pp. 293-301

Special Issue Dedicated to the Memory of Prof. Nguyen Van Dao

\title{
COMPARISON OF SOOT RADIATION IN DIESEL FLAME GIVEN BY MATHEMATICAL MODEL AND BY EXPERIMENTAL DATA
}

\author{
Bui Van Ga, Tran Van Nam \\ The University of Danang \\ NGUYEN NGOC LINH \\ SAMCO, Ho Chi Minh City
}

\begin{abstract}
An integral unidirectional model is established to calculate radiation heat transfer of Diesel flame in the open air and in combustion chamber of engine. Based on the temperature and soot fraction given by the flamlet theory and soot formation model of Tesner-Magnussen, radiation of soot particulate cloud at different positions of flame is determined and compared with experimental data obtained by the two-color method.

The results show that the radiation given by the model is $20 \%$ lower than that produced by experiments on the stationary flame in open air. Soot radiation intensity in the Diesel engine increases in function of load and engine speed regimes and its maximum value (about $2000 \mathrm{~kW} / \mathrm{m}^{2}$ ) is reached when the highest pressure is attained in combustion chamber.
\end{abstract}

\section{INTRODUCTION}

Radiative heat transfer in combustion chamber of Diesel engine is from two sources: gas radiation and soot particulates emission, in which the latter is dominant. In homogeneous mixtures combustion of spark-ignition engine, only a small soot volume is found in combustion products, so major radiation comes from gases such as $\mathrm{H}_{2} \mathrm{O}$ and $\mathrm{CO}_{2}$. The radiative heat transfer in this case is approximated to be about $10 \%$ of the convection heat transfer. But in case of Diesel engine it is estimated that radiative heat transfer in combustion process may account for $40 \%$ of the total heat transfer. This value depends on the shape of the combustion chamber, fuels, engine regime, etc. The major radiation is of soot formed during the diffusion combustion stage in zones with high temperature and rich mixtures [5]. In addition, water vapor, $\mathrm{CO}_{2}$, and other intermediary substances contribute to increase radiative heat transfer. However, radiation of these substances only concentrates on a narrow wavelength band with a very small radiation intensity compared with that of soot radiation. Soot radiation normally accounts for $90 \%$ of the total radiative heat transfer of combustion products.

It is complicated to calculate radiative heat transfer from the diffusion flame to the combustion chamber wall because, besides calculating the relative geometric parameters between the radiator and the receptor, we need to determine the heat radiation coefficient of soot in combustion products [8]. For this reason, in a number of mathematical models of combustion, detailed calculation of radiative heat transfer is ignored. This heat transfer is estimated based on its ratio to the total heat transfer. 
A detailed calculation of radiative heat transfer from the diffusion flame to the combustion chamber wall can be done based on the soot radiation coefficient. This coefficient depends on the soot characteristics which are difficult to determine by means of traditional measuring methods. Blunsdon et al. [1] have developed a radiative heat transfer model to supplement the fluid dynamic model for computation of the Diesel engine burning process. Calculation results show that the maximum temperature in the burning zone reaches about $2800 \mathrm{~K}$, the maximum volumetric fraction of soot about $7 \mathrm{ppm}$ and the maximum radiative heat transfer approximately $450 \mathrm{~kW} / \mathrm{m}^{2}$. Wiedenhoefer et al. [4] have conducted experimental survey to check their own radiation model. According to their experimental results, the radiation intensity depends on turbulence intensity in the combustion chamber, reaching a maximum value of $1.600 \mathrm{~kW} / \mathrm{m}^{2}$ corresponding to turbulence ration at 1.4. Without turbulence in the combustion chamber, Wiedenhoefer's experimental results are similar to those of Blusdon (maximum radiation of $450 \mathrm{~kW} / \mathrm{m}^{2}$ ). The total maximum heat flux transmitted through the combustion chamber wall is $6.000 \mathrm{~kW} / \mathrm{m}^{2}$ as calculated by Eigimeier et al. [3]. These experimental results show that radiative heat transfer from burning gases to combustion chamber wall of Diesel engine accounts for $30-40 \%$ of total heat transfer.

To simplify the effects of geometric elements of the combustion chamber on radiative heat transfer, we have, in our study, calculated the general radiative heat flux transmitted from the flame to the combustion chamber wall by using the following approximate expression:

$$
q_{k w}=\varepsilon_{k} \frac{\varepsilon_{w}+1}{2} C_{o}\left[\left(\frac{T_{k}}{100}\right)^{4}-\left(\frac{T_{w}}{100}\right)^{4}\right]
$$

The temperature of the engine combustion chamber is normally stable thanks to cooler system and calculated to be $T_{w} \approx 700 \mathrm{~K}$, the temperature of radiative burning gases in the Diesel engine $T_{k} \approx 1800-2600 \mathrm{~K}$ and the engine combustion chamber is considered a grey body with $\varepsilon_{w} \approx 0.82$. The problem to be solved is to determine the soot radiation coefficient.

In recent years, mathematical models have been developed to estimate the typical soot parameters. Simple unidirectional soot formation models have been developed to compute the flame in open air and inside the combustion chamber [5]. More complex multilateral models are formulated in such fluid dynamic softwares as KIVA III, FIRES, FLUENT, etc. These softwares whether simple or complicated are based on the soot formation theories, of which the one proposed by Tesner-Magnussen is widely used [5].

Soot emits continuous radiation in the infrared spectrum range and in the visible spectrogram. Accurate prediction of soot radiation can be possible if its optical characteristics such as particulate size distribution and geometric shape are determined. The theory proposed by Mie assumes that soot radiation depends on the particulate size parameter $\alpha=\pi d_{s} / \lambda\left(d_{s}\right.$ is the soot particulate diameter) and optical constants which depend on wavelength. According to this theory, with $\alpha \ll 1$, the diffusion part is simplified in the Rayleigh limit, hence the soot absorption coefficient is determined as following expression:

$$
a_{\text {soot }, \lambda}=\frac{36 \pi n \kappa}{\left(n^{2}-\kappa+2\right)^{2}+4 n^{2} \kappa^{2}} \cdot \frac{f_{v}}{\lambda} .
$$


Experimental results show that soot radiation is independent of wavelength. Thus, by choosing the average value of $n$ and $k$, soot absorption coefficient can be determined by:

$$
a_{\text {soot }}=\frac{C_{0}}{\lambda} f_{v},
$$

where $C_{o}$ is a constant.

Taking integral in the whole spectrum range, the grey soot absorption coefficient is formulated as follows:

$$
a_{\text {soot }}=\frac{1}{\sigma T^{4}} \int_{0}^{\infty} a_{\text {soot }, \lambda} e_{b, \lambda} d \lambda=3.6 \frac{C_{0}}{C_{2}} f_{v} T,
$$

where $e_{b, \lambda}$ is the radiation capacity of the black body, $C_{2}=0.0143879 \mathrm{mK}$ is a constant and $C_{o}=\frac{36 \pi n k}{\left(n^{2}-k^{2}+2\right)^{2}+4 n^{2} k^{2}}$ depends on the real part $n$ and the virtual part $k$ of the soot scattering indicator. $C_{o}$ varies between 3 and 10. In case the soot particulate diameter is small, $C_{o}=7.23$ can be chosen and then $a_{\text {soot }}=1809 f_{v} T$ is obtained.

The soot radiation coefficient is determined by its absorption coefficient:

$$
\varepsilon_{s}=1-\exp \left(-a_{\text {soot }} L\right)
$$

As a result, we obtain:

$$
\varepsilon_{s}=1-\exp \left(-1809 f_{v} T L\right) .
$$

As shown in the above expression, soot radiation coefficient depends on soot volumetric fraction $f_{v}$, the flame temperature $T$ at the measuring location and the optical trajectory length $L$. These parameters can be determined by optical methods; i.e. light diffusion method, two-color method, etc. In this study, radiative heat transfer is calculated via soot parameters determined by the Tesner-Magnussen model. This model is validated by experimental data given by two-color method from diffusion flame in the atmosphere and from combustion chamber of Diesel engine.

\section{SOOT CALCULATION MODEL}

In diffusion combustion, fuel in the high temperature field undergoes pyrolysis to form different organic compositions. Heavy organic composition formulates accumulation centers of light organic elements, making them solid particles. This is called the radical nuclei formation stage. Then, these nuclei are linked together to form bigger particles and at the same time develop their surface and particle volume. The formed soot particles will follow the gas flows in the convection-diffusion process. When soot particles flow through zones of oxygen redundancy and high temperature, they will be oxidized. Unburned particles will be pushed out in open air. In the Diesel engine, these parts of soot present in the exhaust gases and cause environmental pollution.

From the above-mentioned soot formation mechanism, Tesner proposes a two-stage model: the first stage is radical nuclei formation and the second is soot particle formation. Magnussen has contributed to this model by adding the burning rate of soot particles. According to Magnussen, the diffusion combustion process in general and the soot particle burning process in particular can be described by the "eddy-dissipation" model. In this model, the turbulence intensity determines the burning rate because it affects the process of air-fuel mixture which requires much more time than that of chemical reaction. 
Detailed of soot formation procedure based on Tesner-Magnussen model has been described in $[5]$.

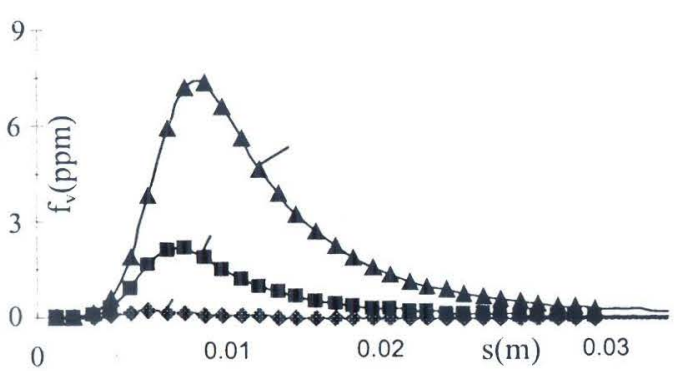

Fig. 1. Influence of the injection spray angle on soot fraction in the combustion chamber (gas flow movement rate $U_{\infty}=4 \mathrm{~m} / \mathrm{s}$ )

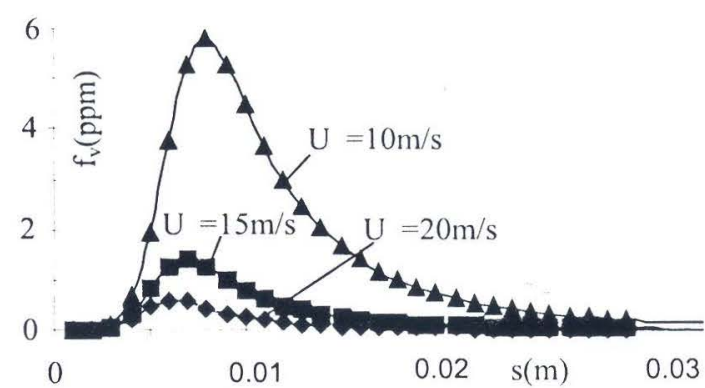

Fig. 2. Influence of gas flow movement rate on soot fraction in the combustion chamber $\theta=\frac{\pi}{4}$

This soot formation model is integrated in the diffusion flame computation procedure to calculate soot concentration at each instant of crank angle. Figures 1 and 2 illustrate the typical computational results of the influence of injection spray angle and surrounding airflow speed on the soot concentration in combustion chamber of Diesel engine. Based on this soot concentration and the burning temperature of the flame, heat radiation can be computed as illustrated in expression (1.1).

\section{EXPERIMENTAL STUDY}

Experiments have been conducted on the diffusion flame in open air and in combustion chamber of Diesel engine. The positioning and methods of carrying out the former and the latter experiments are illustrated in [6] and [7] respectively. The common measuring principle is to use visioscope AVL to record flame radiation at two different wavelengths. The data are then sent to computer memory. By using the thermovision software, the flame data are analyzed by the two-color method and the soot volumetric fraction and temperature are determined at each observation location.

Visioscope AVL uses its 24-bit PixelFly CCD VGA color camera with $640 \times 480$ pixcels resolution, which can take 15 pictures/second. At the current rate of taking pictures of visioscope, to examine the relative flame value at different

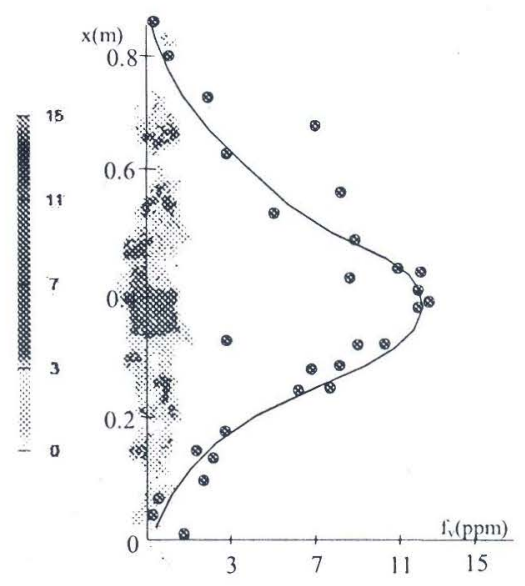

Fig. 3. Distribution of soot fraction according to the flame height given by the two-color method crank angles, some cycles need to be deviated to make the time difference bigger than the time interval between the two consecutive picture shots. Figure 3 shows the results of soot concentration variation depending on the flame height in open air given by the two-color method. The typical result of soot concentration and temperature in the auxilary Mazda 
engine combustion chamber is shown in Figure 4 for the loading regime of 60\%, engine speed of 2000 revolutions $/$ minute and at $9^{\circ}$ crank angle.

\section{RESULTS AND DISCUSSIONS}
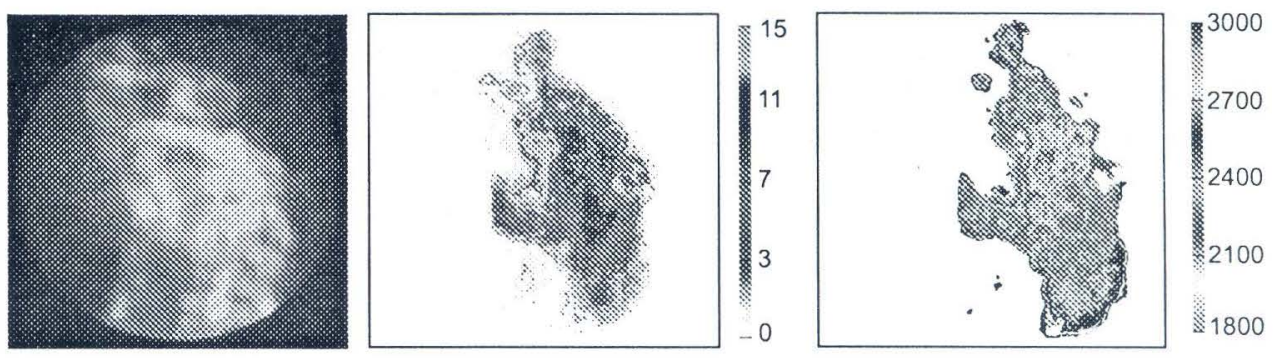

Fig. 4. Picture of flame by visioscope, distribution of soot fraction and temperature given by the two-color method $\left(60 \%\right.$ load, $n=2000 \mathrm{rpm}, 9^{0} \mathrm{CA}$ )

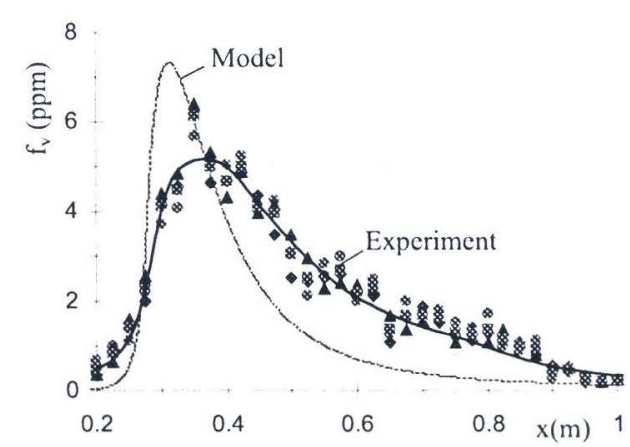

Fig. 5. Comparing soot fractions given by model and by experiment $(\mathrm{Re}=23.180)$

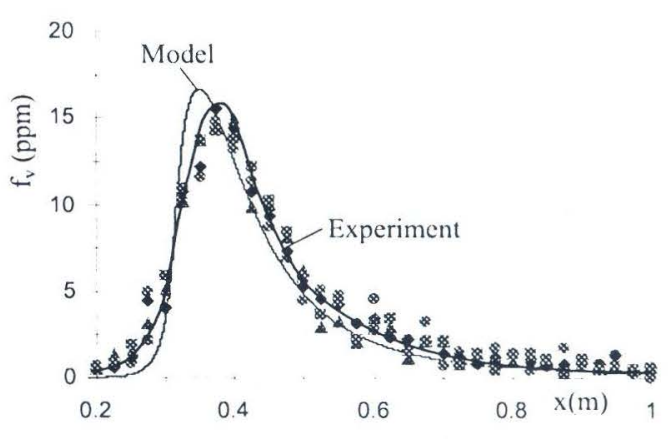

Fig. 6. Comparing soot fraction given by model and by experiment $(\mathrm{Re}=31.020)$

Figures 5 and 6 illustrate a comparison of soot concentration variations given by the model and by experiments corresponding to Reynold number at the nozzle of 23.180 and 31.020. In the initial stage, there is a coincidence of soot concentration increase in the two cases. After reaching the maximum value, soot concentration in the former reduces much more quickly than that in the latter. According to the theory proposed by Tesner-Magnussen, the rate of soot formation depends on combustion temperature and fuel concentration. At the tail of the flame, the temperature in the latter is higher than that in the former, thus allowing for greater soot burning rate.

On the basis of computed soot concentration and diffusion flame tempcrature, heat radiation can be calculated at different positions alongside the height of the flame. In our computation, only heat radiation of the flame is compared as shown in the following expression:

$$
q_{k w}=\varepsilon_{k} C_{o}\left(\frac{T_{k}}{100}\right)^{4} .
$$

Figure 7 shows a comparison of radiation intensity given by the model and by the experiments for the diffusion flame in the open air at the injection pressures of 80, 100 


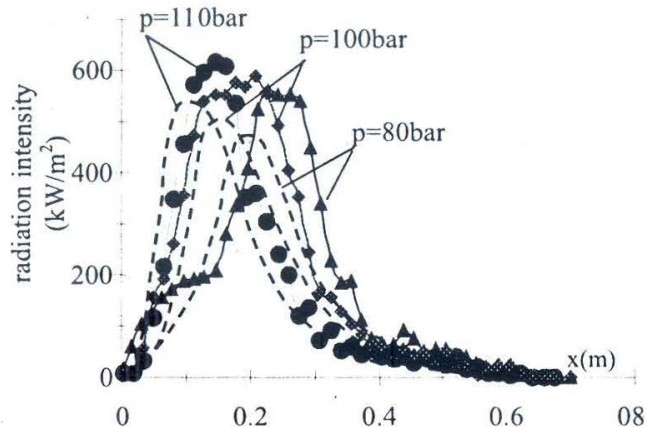

Fig. 7. Comparison of radiation intensity given by the model and by the experiments for the diffusion flame in the air

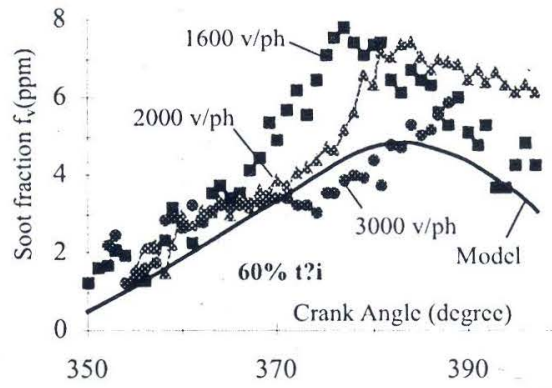

Fig. 8. Variation of soot volumic fraction in auxilary combustion chamber of Mazda engine versus crank angle corresponding to different engine speeds at load regime of $60 \%$

and 110 bars. The model-shown results are similar to those given by experiments however the maximum point given by the model is closer to the nozzle than that given by the experiments. The maximum radiation intensity given by the model is $20 \%$ lower than that given by the experiments. This can be explained by the fact that we, in model computation, assume the fuel to evaporate right after coming out of the injector but in reality fuel is still in the form of particle on leaving the injector. The soot concentration in the fuel particle combustion process is higher than in that of gas mixture combustion.

The model for computing the diffusion flame in the engine combustion chamber is much more complicated than that in open air. In fact, in engine combustion chamber, fuel jet is instationary which present in moving air environment with high variation of pressure and temperature. To simplify the computation, our assumptions are as follows:

1) The injection pressure is stable throughout the injection period;

2) The specific mass of the air beyond the injection spray changes corresponding to the pressure in combustion chamber;

3) The length of the flame at each crank angle position is proportional to the corresponding crank angle value from the moment injection starts;

4) Soot concentration and temperature at each crank angle position is the average value for the whole corresponding flame length;

5) The rate of airflow movement is proportional to the engine speed;

6) The engine load is proportional to the injection pressure;

These assumptions are made for purpose of simplifying the application of the simple diffusion flame model in open air to the complicated conditions of the engine combustion chamber. Due to lacking of experimental parameters related to the airflow movement in the combustion chamber, a set of input parameters has been used including injection spray angle of $\pi / 4$, airflow movement rate of $7 \mathrm{~m} / \mathrm{s}$ and injection pressure of 100 bars for quantitative comparison with experimental data.

Experimentally, to examine radiative heat transfer variations in function of crank angle taking place in auxiliary combustion chamber of the Mazda engine has been recorded by a camera. Based on temperature and soot fraction obtained through flame image analysis, the flame radiation coefficient and radiative heat transfer intensity from the flame to the auxiliary combustion chamber wall of the Mazda engine can be calculated. At a high 


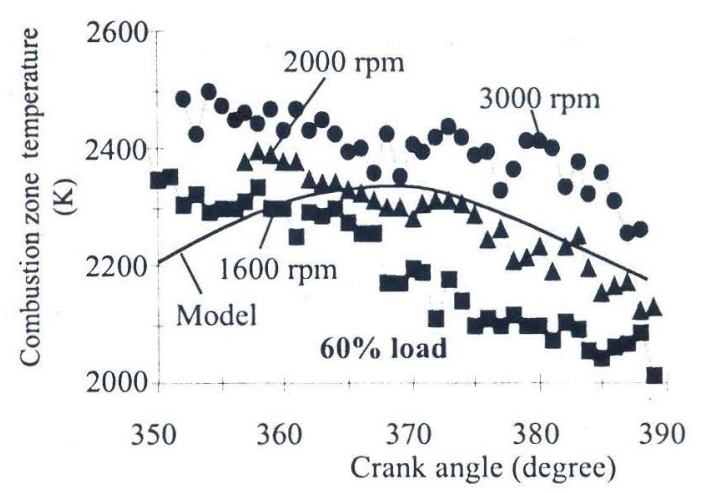

Fig. 9. Combustion zone temperature variations in auxilary Mazda engine combustion chamber according to crank angle corresponding to different engine speeds at the load regime of $60 \%$

engine speed, the turbulence movement of airflow in the auxiliary combustion chamber is strong, local fuel concentration is reduced and hence lowering soot concentration (Figure 8). The maximum soot concentration is from 6 to 8 ppm depending on engine speed. Computation results are shown in Figure 5. The results show that with the input parameters used in computation, the model is coincidal for the engine speed of about $3000 \mathrm{rpm}$. At a smaller engine speed, the airflow movement is weak, which results in high soot concentration. These results are similar to those proposed by Blunsdon and his co-researchers [1]. However, an increase in the mixing rate of air and fuel leads to an increase of burning rate and then of the radiation rate; thus, the combustion zone temperature will increase when the engine speed goes up for the same loading regime (Figure 9). The computation results as shown above coincide with experimenting results in the stage after the engine speed reaches $2000 \mathrm{rpm}$. The computational curve reaches the maximum value at the crank angle of $370^{\circ}$. This is also the position where the pressure in combustion chamber reaches its maximum value. Before this maximum point is reached, there is a considerable difference between the model and the experiment.

Figure 10 shows the variations in radiative heat transfer from the flame to the combustion chamber wall in relation to the crank angle corresponding to different engine speeds. The maximum radiative heat transfer intensity is observed at between $1500 \mathrm{~kW} / \mathrm{m}^{2}$ and $2000 \mathrm{k} \mathrm{W} / \mathrm{m}^{2}$ when the engine speed varies between $1600 \mathrm{rpm}$ and $3000 \mathrm{rpm}$ and this position of maximum value moves towards the top dead center when the engine speed is increased. The radiation intensity is proportional to $T^{4}$, which means, although the amount of soot formation is reduced at high engine speed, the radiative heat transfer intensity is still higher than that at low engine speed.

In Figure 11, variations of radiation intensity versus crank angle corresponding to different load regimes are compared. For a low load regime, the amount of fuel injected into the engine is small, most of the fuel is burnt in the isochoric stage. Radiation in the combustion chamber is caused mainly by the soot created by a small part of fuel undergoing diffusion combustion. A gradual increase in the fuel injected into the engine causes an increase in fuel diffusion combustion and then also in radiation intensity from the flame to the combustion chamber wall. The maximum radiative heat transfer here reaches 2000 $\mathrm{kW} / \mathrm{m}^{2}$ at $80 \%$ load regime. This result is the same as that obtained by Wiedenhoefer and associates [4] for an engine with strong turbulence. An equivalent radiation intensity 
is found in the model computation with the above input parameters for a load regime of $40 \%$ and an engine speed of $2000 \mathrm{rpm}$.

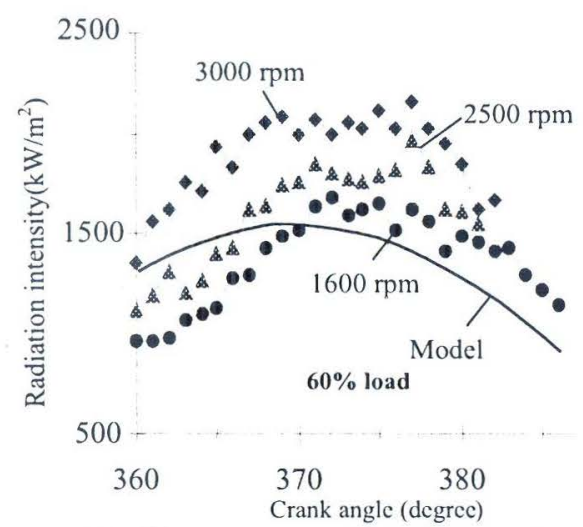

Fig. 10. Comparison of radiative heat transfer intensity from the flame to the combustion chamber wall at different engine speed regimes

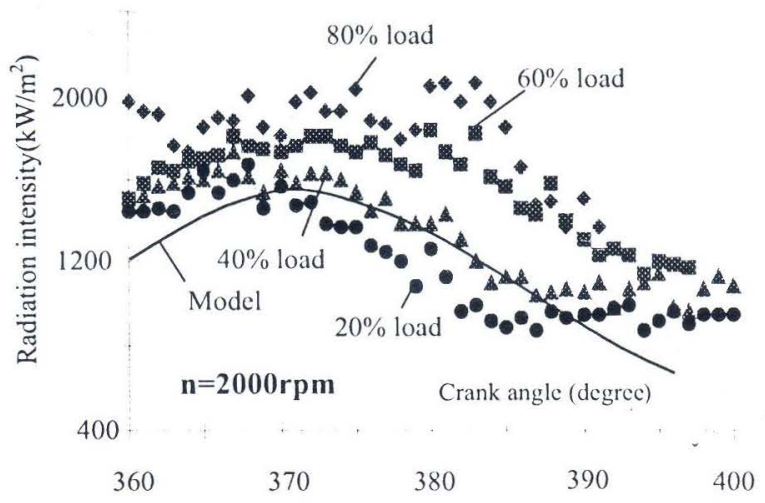

Fig. 11. Comparison of variations in radiation intensity from the flame to the auxiliary chamber wall of Mazda engine in relation to Crank angle corresponding to different load regimes $(\mathrm{n}=2000 \mathrm{rpm})$

The above comparative results show that variations in heat radiation in function of flame height (for the diffusion flame in open air) and in function of crank angle (for the Diesel engine) given by the model and by the experiments have the same forms. The maximum value of heat radiation given by the models with the proposal set of parameters is nearly identical with that produced by experiments. However, in order to have an exact calculation of flame radiation intensity in the engine, a procedure for airflow movement calculation in the combustion chamber are should be incorporated.

\section{CONCLUSIONS}

A soot radiation model is established basing on combination of unidirectional model of diffusion flame and soot formation model of Tesner-Magnussen. The result given by the model is by $20 \%$ lower than that produced by experiments on the stationary flame in open air.

Soot radiation intensity in the Diesel engine increases in function of engine speed and load regimes and its maximum value (about $2000 \mathrm{~kW} / \mathrm{m}^{2}$ ) is reached when the highest pressure is attained in combustion chamber.

The unidirectional model allows us to predict the maximum value and tendency of variations in radiation intensity in relation to the flame height in open air and to the position of the crank angle in Diesel engine. However, to examine the relative variations in soot radiation for different operation regimes of engine, parameters related to the airflow movement in the combustion chamber are needed.

The present research is funded by the National Fundamental Scientific Research Program 


\section{REFERENCES}

1. C. A. Blunsdon, W. M. G. Malalasekera, J. C. DENT, Application of the Discrete Transfer Model of Thermal Radiation in a CFD Simulation of Diesel engine Combustion and Heat Transfer, SAE Technical Paper Series 922305, 1992.

2. P. Furmanski, J. Banaszek, T. S. Wisniewski, Radiation Heat Transfer in a Combustion Chamber of Diesel Engine with Partially Transparent Burnt Gas Zone, SAE Technical Paper Series 980504, 1998.

3. C. Eigimeier, H. Lettmann, G. Stiesch, G.P. Merker, A detailed Phenomenological Model for Wall Heat Transfer Prediction in Diesel Engines, SAE Technical Paper Series 2001-01-3265, 2001.

4. J. F. Wiedenhoefer, R. D. Reitz, Multidimensional Modeling of the Effects of Radiation and Soot Deposition in Heavy-duty Diesel Engines, SAE Technical Paper Series 2003-01-0560, 2003.

5. Bui Van Ga, Le Van Lu, Nguyen Ngoc Linh, An evaluation of the Tesner-Magnussen soot formation model by experiments on the diesel flame, The $8^{\text {th }}$ National Fluid Mechanics Conference, pp. 98-107, Ha Tien, 20-22/7/2004.

6. Bui Van Ga, Phung Xuan Tho, Pham Xuan Mai, Le Van Lu, Nguyen Ngoc Linh, Soot formation analysis in turbulent diffusion flames by Visoscope, International Automotive Congress CONAT 2004, Brasov, Romania, 19-22 October 2004

7. Bui Van Ga, Duong Viet Dung, Huynh Ba Vang, Nguyen Ngoc Linh, Temperature and Soot Distribution Analysis in Pre-Chamber of MAZDA WL Engine by AVL Visioscope, Paper 042, International Conference on Automotive Technology for Vietnam, ICAT 2005, Hanoi, October 22-24, 2005.

8. Bui Van Ga, Tran Thanh Hai Tung, Huynh Ba Vang, Le Van Lu, Nguyen Ngoc Linh, An empirical study of heat radiation coefficient of the diffusion flame, Science and Technology Journal 15 (2006), The University of Danang.

Received July 29, 200\%.

\section{SO SÁNH BỨC XẠ NHIỆT CƯA BỒ HÓNG TRONG NGỌN LỬA DIESEL CHO Bởi MÔ HİNH TOÁN HỌC VÀ THỰC NGHIỆM}

Mô hình tích phân một chiều được xây dựng để tính toán bức xạ nhiệt của ngọn lửa diesel cháy ngoài khí quyển và trong buồng cháy động cơ. Trên cơ sở nhiệt độ và nồng độ bồ hóng cho bởi lý thuyết màn lửa mỏng và mô hình tạo bồ hóng của Tesner-Magnussen, bức xạ nhiệt của đám mây bồ hóng tại các vị trí khác nhau trong ngọn lửa được xác định và so sánh với số liệu thực nghiệm cho bời phương pháp hai bước sóng.

Kết quả cho thấy bức xạ nhiệt của bồ hóng tính toán theo mô hình nhỏ hơn $20 \%$ so với giá trị thực nghiệm trên ngọn lựa đứng yên ngoài khí quyển. Cường độ bức xạ của bồ hóng trong buồng cháy động cơ diesel tăng theo chế độ tải và chế độ tốc độ và đạt giá trị cực đại ở vị trí áp suất trong buồng cháy lớn nhất. Cường độ bức xạ của bồ hóng trong buồng cháy dự bi cùa động cơ diesel đạt khoảng $2000 \mathrm{~kW} / \mathrm{m}^{2}$ 